\title{
EDUCATION IN OUT-OF-SCHOOL FORMS FOR CHILDREN - TO CHANGE THINKING ABOUT THE FUTURE
}

\begin{abstract}
Kasprzak Michalina, Education in Out-Of-School Forms for Children - to Change Thinking About the Future [Edukacja pozaszkolna dzieci - zmienić myślenie o przyszłości]. Studia Edukacyjne nr 41, 2016, Poznań 2016, pp. 227-236. Adam Mickiewicz University Press. ISSN 1233-6688. DOI: $10.14746 /$ se.2016.41.14
\end{abstract}

Non-formal education is undervalued nowadays. The importance of education establishments is greater for children and young people who come from families with a lower socioeconomic status. In this paper I would like to present the potential and possible changes of Free Educational Centres for children with a lower socioeconomic status. Children using additional educational institutions free of charge can get the chance for a better future.

Key words: Common Centres, out-of-school education, socioeconomic background, support children

\section{Introduction}

In 1986 the Professor William Douglas Wall wrote about the need for mutual acceptance of school, family home and society:

We need to find such ways and methods of teaching, which would enable not only positive and creative education in the traditional program, but which would ensure cooperation with other, even more powerful educators in houses and in the local environment. ${ }^{1}$

\footnotetext{
1 W.D. Wall, Twórcze wychowanie w okresie dzieciństwa, Warszawa 1986, p. 18.
} 
In my opinion nowadays we have the same problem with out-of-school forms education for children in Poland. School programs do not keep up with the creative process of upbringing and education of children. Although the positive views on the work of teachers in schools, they are not able to help all children in the same way.

The education system in Poland is the same as in most countries of the European Union. Children begin compulsory full-time education from the 6 years old, and compulsory part-time education is until the age of $18^{2}$ then young people can take part in the non-compulsory education. During the period compulsory and non-compulsory education of children and young people can benefit from out-of-school forms education. In out-of-school forms for children in Poland education is divided on paid and free institutions. Access to paid education is limited for children and young people who come from families with lower socioeconomic status. This situation causes for example threat to the orderly development of children with lower socioeconomic status. ${ }^{3}$ Moreover it causes the uneven beginning of the education for all children. However it is contrary to general tasks of the education in the country, because "public authorities provide citizens with general and equal access to education". 4

Every child should have access for the safe education, as well as have a chance to study irrespective of the origin. Free action at institutions should and so be the same professional as the ones paid. Ewa Wysocka is giving basic conditions with actions to support the development of children. For her action's view should be: effective, possible for the accomplishment, to have a quality (she is combining them with the preparation of the knowledge and skills to practice the profession, with the personality of the employee and the social-cultural context)..$^{5}$ Following this way of thinking in Poland we still have a situation with increasing problems of social inequalities, because paid activities for children (paid by their parents or guardians) often are better quality than free. This is one of the reasons for the underestimation of non-formal education in Free Educational Centres.

2 Polish Eurydice Unit, The System of Education in Poland in Brief 2015, http://eurydice. org.pl/wp-content/uploads/2016/01/BRIEF_EN_FINAL2015.pdf, [17.02.2016], p. 2.

${ }_{3}$ M. Stępień, Kultura, kompetencja i szkoła: zagrożenia rozwoju dzieci o niższym statusie socjoekonomicznym, [in:] Dzieci i młodzież w niegościnnym świecie. Zagrożenia rozwojowe i społeczne, Ed. E. Wysocka, Warszawa 2012, p. 253-255.

4 Polish Eurydice Unit, The System of Education in Poland in Brief 2015, p. 2.

${ }^{5}$ E. Wysocka, Wspomaganie rozwoju młodego pokolenia - problemy i zasady pomagania, [in:] Dzieci i młodzież w niegościnnym świecie, p. 342-344. 
In this paper I will discuss the difficulty in out-of-school education in Free Educational Centres (especially about Common Centres in case of Poznan) and then I will raise a question about the future of creative learning in these places. I will try to present my view for non-formal education, especially in Free Educational Centres in Poland.

\section{The spark of hope - Free Educational Centres in Poland: the case of Poznan}

In Poland, Free Educational Centres are one of the forms of daily support for children from families with lower socioeconomic status for example poor families, families with alcohol problems, families excluded from society and others. Social and educational inequalities they are accumulating, when the child comes from such a family. Children from families with lower socioeconomic status generally have a more learning disabilities and they have problems with adaptation to the social and cultural norms. ${ }^{6}$ This leads to educational, social and cultural barriers for a child not only at school and nowadays, but also has a affects on the child's future.

According to obtained data from the Central Office in Poznan in 2016 in Poland functions several tens of thousands institutions of daily support for children and teenagers, and in Poznan functions 11 registered Common Centres (Free Educational Centres). ${ }^{7}$ They are these are institutions which are acting in the local environment, not directly by schools. Usually, they are conducted by NGO institutions but some Common Centres receive subsidies from the city. The every of Common Centres has own regulations, however accepts children ages from 6 to 18 years old. In each of them a division into a peer group is during the additional classes, it is usually younger group: from $6-13$ years and the older group from 14 - 18 years. Moreover every child in Common Centres can get a warm meal and educator can help with their homework and the organization of free time. ${ }^{8}$ The Free Educational Centres in the local environment are open a few hours of the day, usually about 4 to 5 hours from Monday to Friday. These are a place where children can come after school and spend free time in a safe place.

${ }^{6}$ G. Cęcelek, Sytuacja szkolna dziecka z rodziny ubogiej, Warszawa 2011, p. 92-93.

7 Telephone information service from Central Office in Poznan, 9 February 2016.

8 Ustawa z 9 czerwca 2011 r. o wspieraniu rodziny i systemie pieczy zastępczej (DzU nr 149 z 2011 r., poz. 887 z późn. zm.), art. 24. 
Sometimes it happens that children prefer to spend time on the street. From various reasons children are making such choice: it is often associated with family problems, health problems, failures at school, negative emotions, not-accepting by a peer group, and also not accepting yourself. ${ }^{9}$ One should notice, that I am trying to divide children of the streets and children from socially problem of families which are attending in Free Educational Centres, because it is definitely more complicated problem. However these information can show, that Free Educational Centres (or Common Centres) aren't in Poland an only way out for children with diverse problems. The welfare of children is here only common denominator, which should be changed and shaped according to current needs of children. ${ }^{10}$

From my observation and scientific research conducted from 2014 it results that still we have a problem with the organization of the help to children in Free Educational Centres in the local environment. In 2014, I conducted scientific research of teachers who work in Common Centres in Poznan (44 people, who worked in 8 Free Educational Centres for children in the local environment). Teachers in opened questions pointed at problems from:

- the financial conditions;

- the place conditions;

- not enough educational equipment;

- not enough teachers, educators or specialist;

- not enough time for individual work with a child;

- not interesting program for children;

- the cooperation with others institution;

All of teachers-respondents indicated that financial assistance is needed, and necessary for working with children. Teachers declared that Common Centres receive the assistance from local companies, from the foundation, from other sponsors, however still the help is insufficient. In addition, $7 \%$ of them think that Common Centres need additional financial resources to continue their activity. On workplace - $80 \%$ teachers declared that there is a need for greater space (a minimum of one room more), renovation or a new place, so as not to disturb the development possibilities of children. Further, the teachers talked about educational equipment, form them $84 \%$

${ }_{9}$ N. Stolińska-Pobralska, Problem dzieci ulicy w kontekście zjawiska defaworyzacji społecznej, [in:] Psychospołeczne uwarunkowania defaworyzacji dzieci i młodzieży, Eds. K. Hirszel, R. Szczepanik, A. Zbonikowski, D. Modrzejewska, Warszawa 2010, p. 28-29.

${ }^{10}$ K. Frysztacki, M. Nóżka, M. Smagacz-Poziemska, Dzieci ulicy. Studium szczególnego problemu miejskiego, Warszawa 2011, p. 90. 
regarded in Common Centres is not enough: computers, modern educational games, books and art materials. The next issue, in the opinion of teachers $-50 \%$ respondents - in the Common Centres special staff is needed, for example: the psychologist, the psychotherapist, the sociotherapist and other specialists, who will be able to work with children once a week. The absence of staff is related with insufficient amount of time for every child. This problem noticed $68 \%$ of teachers. Concerning issue of the not interesting programme's of work with the child indicated $23 \%$. It is problem very much folded which I will discuss in detail in the next subsection. The last mentioned problems concerned the cooperation with other institutions supporting the education and the child development, and also with the family, the school and institutions of care and upbringing of the child. The teachersrespondents showed that $95 \%$ of them had a problem with the contact with parents of the child, and similarly a cooperation with other institutions $-7 \%$ of them cooperates with other institutions.

The results of my research in this field showed the opinions by teachers about the current situation in Free Educational Centres. Without doubt showed a special need for change in the Common Centres in the local environment, moreover, they showed how important it is to create these and similar places for children. Taking up the challenge to work in such a difficult environment teachers should remember about the welfare of children and the help to them in the problem solving, but also to teach them dealing with the emotional, social and cultural pressures. Activity of Common Centres in the local environment is important, these institutions often constitutes the only form of child's support. In the opinion Renata Szczepanik from the standpoint of preventing social isolation of children from communities threatened of demoralization, demoralized and poor families - in the organization and action of such Free Educational Centres, as Common Centres or Clubs is many traps. The organising authorities Common Centres should be careful, although not undermined are the purposes and effects: social, sociotherapeutic and psychological action taken by them, and also there is a high risk of stigmatization of children who come from families with lower socioeconomic status. In her opinion Common Centres can enhance the social divisions. ${ }^{11}$ In my opinion if the environment will be closed and the organizers will not be want to cooperate with other institutions, with families and the local environment may be result a negative stigmatization of chil-

11 R. Szczepanik, Wptyw instytucji "pomocowych" na proces wykluczenia spotecznego dzieci i młodzieży zagrożonej demoralizacja, [in:] Psychospoteczne uwarunkowania defaworyzacji dzieci i mtodzieży, p. 36-40. 
dren. In this case, they can find the "golden mean" (if will be possible) only with the balance, an optimal and positive attitude for the conducted there actions.

\section{Towards effectivenesses of action taken in Free Educational Centres}

In the section in out-of-school education is a large field of action. Nowadays children spend a lot of time outside of school, without adult supervision. ${ }^{12}$ Therefore, the organization of all action outside of school in the leisure time for children is necessary. Following the road forms of free education for children, I think that Free Educational Centres in Poland are a necessary form of work with children who come from families with lower socio-economic status, but also it is one of forms which certainly should be transformations. In this publication I will try to present my proposals for changes. I will concentrate mainly on the changes, which teachers can carry on at the direct work with child. Other issues abovementioned by teachers I will leave for self-analysis, because in my opinion the financial, place and material conditions are possible to solve. First, I will undertake the issue of a not interesting programme of work with children, then the problem with not enough time for individual work with a child, and at the end the situation about cooperation with others institution.

The problem of interesting activities for children organized by teachers is for many years very universal (not only in out-of-school forms). Unfortunately, it is a problem mainly connected with creative competence, of both children and teachers.

Creative work is fulfilling beyond our efforts. People remain open when they create. This openness enables them to deeply connect to Other with similar experiences, surpassing time and space..$^{13}$

Readiness to take on challenges of professional is not the most important component. The effectiveness in education can be achieved with a creative teacher who not only shares his knowledge but also shows the way creative development of children. Him or her should be characterized: reflectivity, care of authority, enthusiasm, good organization, integrated vision of one-

$12 \mathrm{H}$. Eshach, Bridging In-school and Out-of-school Learning: Formal, Non-Formal and Informal Education, Journal of Science Education and Technology, 2007, 16, 2, DOI: 10.1007/s10956-0069027-1, p. 171.

13 E. Prijatelj, The understanding of creativity and its place in education, [in:] Education and Creativity, Ed. E. Osewska, Warsaw 2014, p. 15. 
self, cooperation with other teacher or educators and volunteers, selfcriticism and multi-faceted in enriching oneself. ${ }^{14}$ In fact, there is a problem with finding an employee who wants to work, with children who are marginalized in different environments. In the last years, during the course of high interest the creative individual and the development we are looking for professionals and strive to idealized model of teacher. However, the creative should not be only teacher. "Creativity in the creative education is sought not from special human field but from human generality". ${ }^{15}$ The child can also be creative. Joy Guilford proposed that

creative individuals are characterized by a combination of personality traits such as: sensitivity to problems, ideational fluency, flexibility for adaptation, originality, synthesis capacity, analysis capability, reorganization and redefinition competence, complex data assimilation, and by being capable of evaluate ideas. ${ }^{16}$

These and other characteristics can have the adult as well as the child. The role of the teacher is to create the space for children to increase their development of skills and competences. In my opinion, to the attractiveness of activities, and greater support for children in Free Educational Centres should be: individual assistance plan for each child; time for an individual meeting with the tutor; educational work in tandem: the child - the teacher; and if the child needs meet with a psychologist or other specialist. It is precisely the time which teachers dedicate to a child who comes from a family with a lower socioeconomic status, the possibility of a personal conversation makes his interest of this place. At the next place are additional classes.

Children who come from families with lower socioeconomic status often have educational failure, for this reason, in Free Educational Centres classes should be more original. Nowadays avoidance of new technologies in education does not make sense. Irrelevant on economic status, the children are very interested in the dynamically developing new media environment. For example, in the United States used the Internet in drug prevention programs BrainTrain4Kids.com - it is a program for children in 7 to 9 years old, where

the primary objective of the curriculum is to provide an early foundation for drug abuse prevention efforts by educating elementary school-aged children about the brain and how alcohol, tobacco, and drugs can harm it. ${ }^{17}$

${ }^{14}$ J. Mastalski, Creative catechist, that means who? [in:] Education and Creativity, p. 79-80.

15 Y.G. Lee, The Teaching Method of Creative Education, Creative Education, 2013, 4, 8A, p. 26.

16 J. Guliford, Creativity: A Quarter Century of Progress, from: N. Píriz Giménez, Profile of Promoters and Hindering Teachers Creativity: Own or Shared? Creative Education, 2016, 7, p. 1437.

17 M.P. Assessment of an Interactive Internet Program to Educate Children Aged 7 - 9 about Science, the Brain and Drugs [Abstract], Creative Education, 2013, 4, 11, p. 683-693. 
Another example is education through mobile phones for the participation of the whole family, not only children but also their parents. ${ }^{18}$ In Singapore was created a project of formal and non-formal education with the use of mobile technologies. ${ }^{19}$ May be claim that this situation is far from us, but in my opinion this is one of the ways to work with children. I think that it is possible to make a very interesting activities for children from lower socioeconomic status. One of my proposals may be the use of students' knowledge from Computer Science, for example on creating graphics, movies or websites. Equipment may be obtained from European Union's funds, with competitions or sponsors. Another form towards attractive courses for children, would be to promote of author's programs of teachers. In the 21st Century in Poland teachers should be concentrated on the interaction, information and communication technologies not only for children, but also for multi-development of them..$^{20}$

The last of the changes in Free Educational Centres, I would propose enhance cooperation with: family, school, local community and the institutions involved in the care, development and support of the child. The family environment is very important for physical and psychological development of the child. Cooperation with the school and other institutions would help teacher or educators in Free Educational Centres with an indication situation and pupil's functioning in the school and the closest background. Local companies could join in the action to support of Free Educational Centers in their work for children and families. Finally, the cooperation of workers with family could be in the direction of strengthening the work of teachers, educators and volunteers also in a family environment.

\section{Summary and conclusions}

The most of teachers in Free Educational Centres, especially in Common Centres in Poznan need changes, that are unavoidable as a result with changes in compulsory education. Also important are the changes in the thinking of people to as a community to strive for the good of the child. In my vision of cooperation the basic to start work s a child. Then the coopera-

18 Q. Shahnaz et al., Effectiveness of Parent Education through Mobile Technology in Afghanistan, Creative Education, 2014, 5, p. 1921-1928.

19 C-K. Looi, et al., Bridging Formal and Informal Learning with the Use of Mobile Technology, Future Learning in Primary Schools, A Singapore Perspective, 2016, 10.1007/978-981-287-579-2_6, p. 79-96.

${ }^{20}$ E. Osewska, Education and Internet challenges, [in:] Education and Creativity, p. 42. 
tion of his or her family environment. At the next level are the staff of Common Centres and the lider of them. In Free Educational Centres very helpful of group (I think that is still undervalued in Poland) are volunteers. The teacher does not need to know everything. The use of help from other people in strengthening the educational potential of children from lower socioeconomic status may be used in the future. Moreover, cooperation with young people (volunteers) can also cause minimization of the differences between the higher and lower social class. In some environments it is considered that free help is worthless. In my opinion, without a free education for children (not only for children from families with lower socio-economic status) and without the cooperation we are not able to care of a multi-faceted development of the child. Research shows that socioeconomic background is important for the child relative to educational attainment. ${ }^{21}$

The next level of my vision in out-of-school education in Free Educational Centres is cooperation from child, family, teachers, educators and volunteers with other workers (for example psychologist, sociotherapist and other specialist) and with pedagogue in school of the child and other local institutions (for example streetworkers, social workers, public workers, and foundations, associations or companies). The aim of Common Centres is development and welfare of each child. As Common Centers will operated depends not only from the staff, but also from the environment. This model is a very optimistic perspective for Free Educational Centres in Poland, because I think that is the potential of professional development. As a result, if in Common Centres would a changes of activities, development programs will be far more effective and much more powerful.

\section{BIBLIOGRAPHY}

Cęcelek G., Sytuacja szkolna dziecka z rodziny ubogiej, Wydawnictwo Akademickie Żak, Warszawa 2011.

Entrich S.R., Effects of investments in out-of-school education in Germany and Japan, De Gruyter, Contemporary Japan, 2014, 26(1).

Eshach H., Bridging In-school and Out-of-school Learning: Formal, Non-Formal and Informal Education, Journal of Science Education and Technology, 2007, 16, 2.

Frysztacki K., Nóżka M., Smagacz-Poziemska M., Dzieci ulicy. Studium szczególnego problemu miejskiego, Wydawnictwo Uniwersytetu Jagiellońskiego, Warszawa 2011.

${ }^{21}$ For example: S.R. Entrich, Effects of investments in out-of-school education in Germany and Japan, Contemporary Japan, 2014, 26(1), p. 71-102. 
Hirszel K., Szczepanik R., Zbonikowski A., Modrzejewska D. (red.), Psychospołeczne uwarunkowania defaworyzacji dzieci i młodzieży, Wydawnictwo Difin, Warszawa 2010.

Lee Y.G., The Teaching Method of Creative Education, Creative Education, 2013, 4, 8A.

Looi C-K., Lim K.F., Pang J., Koh A.L.H., Seow P., Sun D., Boticki I., Norris C., Soloway E., Bridging Formal and Informal Learning with the Use of Mobile Technology, Future Learning in Primary Schools, A Singapore Perspective, 2016.

Mastalski J., Creative catechist, that means who? [in:] Education and Creativity, Ed. E. Osewska, Cardinal Stefan Wyszynski University Press, Warsaw 2014.

Metcalf M.P., Assessment of an Interactive Internet Program to Educate Children Aged 7 - 9 about Science, the Brain and Drugs [Abstract], Creative Education, 2013, 4, 11.

Osewska E., Education and Internet challenges, [in:] Education and Creativity, Ed. E. Osewska, Cardinal Stefan Wyszynski University Press, Warsaw 2014.

Osewska E. (ed.), Education and Creativity, Cardinal Stefan Wyszynski University Press, Warsaw 2014.

Píriz Giménez N., Profile of Promoters and Hindering Teachers Creativity: Own or Shared? Creative Education, 2016, 7.

Polish Eurydice Unit, The System of Education in Poland in Brief 2015, http://eurydice. org.pl/wp-content/uploads/2016/01/BRIEF_EN_FINAL2015.pdf.

Prijatelj E., The understanding of creativity and its place in education, [in:] Education and Creativity, Ed. E. Osewska, Cardinal Stefan Wyszynski University Press, Warsaw 2014.

Shahnaz Q. et al., Effectiveness of Parent Education through Mobile Technology in Afghanistan, Creative Education, 2014, 5.

Stępień M., Kultura, kompetencja i szkoła: zagrożenia rozwoju dzieci o niższym statusie socjoekonomicznym, [in:] Dzieci $i$ młodzież w niegościnnym świecie. Zagrożenia rozwojowe i społeczne, Ed. E. Wysocka, Wydawnictwo Akademickie Żak, Warszawa 2012.

Stolińska-Pobralska N., Problem dzieci ulicy w kontekście zjawiska defaworyzacji społecznej, [in:] Psychospołeczne uwarunkowania defaworyzacji dzieci i młodzieży, Eds. K. Hirszel, R. Szczepanik, A. Zbonikowski, D. Modrzejewska, Wydawnictwo Difin, Warszawa 2010.

Szczepanik R., Wptyw instytucji "pomocowych" na proces wykluczenia społecznego dzieci i młodzieży zagrożonej demoralizacja, [in:] Psychospołeczne uwarunkowania defaworyzacji dzieci i młodzieży, Eds. K. Hirszel, R. Szczepanik, A. Zbonikowski, D. Modrzejewska, Wydawnictwo Difin, Warszawa 2010.

Ustawa z 9 czerwca 2011 r. o wspieraniu rodziny i systemie pieczy zastępczej (DzU nr 149 z 2011 r., poz. 887 z późn. zm.).

Shahnaz Q., George P., Son V., Shabnam H., Habib S., Schroeder J., Karim Q., Effectiveness of Parent Education through Mobile Technology in Afghanistan, Creative Education, 2014, 5.

Wall W.D., Twórcze wychowanie w okresie dzieciństwa, Państwowe Wydawnictwo Naukowe, Warszawa 1986.

Wysocka E., Wspomaganie rozwoju młodego pokolenia - problemy i zasady pomagania, [in:] Dzieci $i$ młodzież w niegościnnym świecie. Zagrożenia rozwojowe $i$ społeczne, Wydawnictwo Akademickie Żak, Warszawa 2012.

Wysocka E. (ed.), Dzieci i młodzież w niegościnnym świecie. Zagrożenia rozwojowe i społeczne, Wydawnictwo Akademickie Żak, Warszawa 2012. 